\title{
Genetic differentiation and evolutionary process of speciation in the Idotea chelipes complex (Crustacea, Isopoda)
}

\author{
Faouzia Charfi-Cheikhrouha ${ }^{\mathrm{a} *}$, Marc Laulier ${ }^{\mathrm{b}}$, \\ Emmanuelle Hamelin ${ }^{c}$, Jean-Pierre Mocquard ${ }^{c}$ \\ a Laboratoire de biologie animale, faculté des sciences, \\ campus universitaire, 1060 Tunis, Tunisia \\ b Laboratoire de biologie animale, faculté des sciences, \\ Avenue Olivier Messiaen, 72085 Le Mans cedex, France \\ c Laboratoire de génétique et biologie des populations de crustacés, \\ 40, Avenue du Recteur Pineau, 86022 Poitiers cedex, France
}

(Received 29 December 1997; accepted 7 April 1998)

\begin{abstract}
Genetic differentiation and evolutionary relationships among 12 populations, representing three subspecies of the polytypic Idotea chelipes were studied by examining geographic variation at 13 loci assayed using polyacrylamide gel electrophoresis. Interbreeding tests and isozyme variations were investigated to compare these three subspecies and Idotea balthica and to see whether morphological differences coincided with genetic differentiation. A dendrogram using Nei's genetic distance values and a pattern of speciation are reported. The taxinomic status, both specific and subspecific, were confirmed. (c) Inra/Elsevier, Paris
\end{abstract}

Idotea / cross breed / genetic distance / speciation

Résumé - Différenciation génétique et processus évolutif de la spéciation d'Idotea chelipes (Crustacé Isopode). Idotea chelipes a été définie, sur la base des critères morphologiques et de l'hémocyanine, comme espèce polytypique qui groupe trois sous-espèces : I. c. bocqueti, I. c. mediterranea et I. c. chelipes. Le statut taxinomique de ces trois sous-espèces est réexaminé en utilisant les données du polymorphisme enzymatique et les résultats des tests d'interfertilité par comparaison avec une autre espèce, Idotea balthica. Douze populations d'I. chelipes ont été analysées par électrophorèse sur gel de polyacrylamide mettant en évidence 13 loci. À partir des fréquences alléliques, les distances génétiques de Nei ont été estimées. Celles-ci sont

\footnotetext{
* Correspondence and reprints
} 
faibles entre les populations mais augmentent entre les sous-espèces et deviennent importantes entre les espèces. Un dendrogramme est construit et un modèle de spéciation est proposé. Les statuts taxinomiques, spécifique et subspécifique sont confirmés. (C) Inra/Elsevier, Paris

Idotea / hybridation / distance génétique / spéciation

\section{INTRODUCTION}

Idotea chelipes [22] was determined as a polytypic species including three subspecies, bocqueti, mediterranea and chelipes, on the basis of morphological resemblance and study of hemocyanin when compared with Idotea balthica basteri [1]. These subspecies or geographical races occupy, respectively, the eastern Mediterranean basin (eastern Tunisia coasts), the western Mediterranean basin (north Tunisia and south French lagoons) and the Atlantic coasts (Morocco, Spain, France), North Sea and Baltic.

The majority of the I. chelipes subspecies features, particularly those concerning the secondary sexual male characteristics are identical. However, they are very different from $I . b$. basteri ones [8].

Similar observations were reported that concern the hemocyanin electrophoretic mobility and its molecular weight. Hemocyanin, used as a crustacean specific marker, showed the same relative electrophoretic mobility and the similar molecular weight within I. chelipes subspecies. Thus, we observed clear differences between I. chelipes and I. b. basteri $[4,9]$.

The former results, when combined with some minor morphological characteristics (coxal plates and pleotelson shape) and with biochemical markers [7], allowed the following:

- to confer a subspecific level to I. bocqueti, the endemic species of the eastern Tunisia coasts, which was described as a new species [26];

- to separate the western Mediterranean and the Atlantic I. chelipes populations into two subspecies, I. c. mediterranea [4] and I. c. chelipes [22].

The purpose of the present paper is to verify this viewpoint. Two approaches are used:

- breeding tests to determine whether genetic divergence is high enough for the populations or the subspecies to be considered as separate species;

- enzymatic polymorphism to estimate the intraspecific and the interspecific genetic divergence.

\section{MATERIALS AND METHODS}

Laboratory cross-breedings were tested: intrasubspecific, intersubspecific and interspecific crosses were made.

Electrophoretical study used specimens collected from natural populations ( figure 1). Descendants and hybrids obtained from laboratory intra or interspecific cross-breedings were used to determine the genetic control of the different allozymes. Thirteen populations were submitted to enzymatic analysis:

- Arcachon basin (A) and Pouliguen salt-marsh (P) from Atlantic coasts;

- Leucate (L), Canet (C), Gruissan Salin (GS), Ichkeul (I), Bizerte (B), Ghar-el-Melh (GM) and Tunis (T) from western Mediterranean lagoons; 


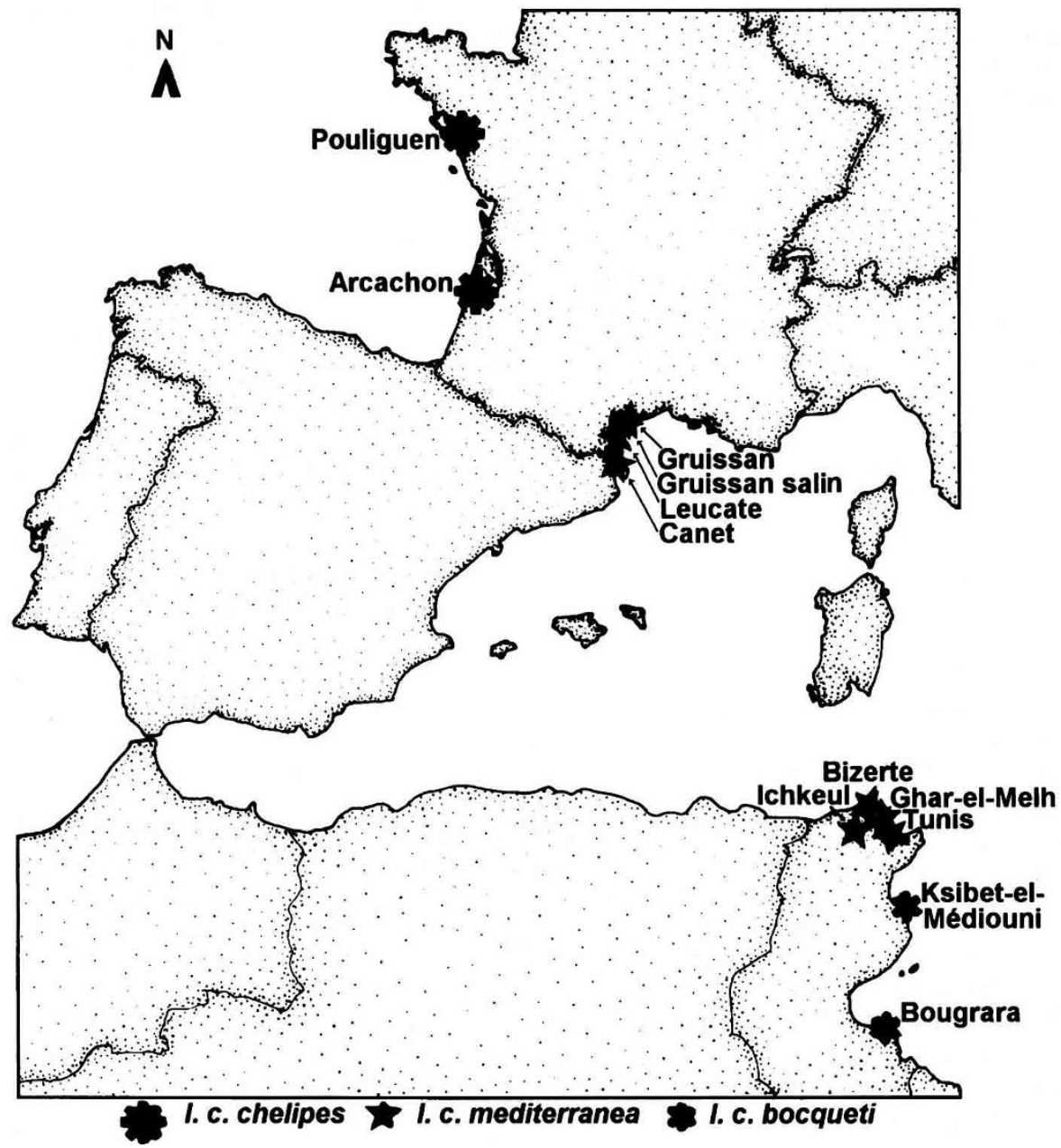

Figure 1. Sampling areas of Idotea chelipes: I. c. chelipes (Atlantic coasts); I. c. mediterranea (western Mediterranean basin); I. c. bocqueti (eastern Mediterranean basin).

- Ksibet-el-Médiouni (K), Bougrara (BG) from eastern Tunisia coasts;

- I. b. basteri population of Bizerta Lake was used as an outgroup to compare the three geographical I. chelipes subspecies described above with this I. balthica basteri.

The enzymatic polymorphism was studied on polyacrylamide gels. Specimens at stage $\mathrm{C}$ of the moult cycle interecdysis [12] were homogenized in a migration buffer (Tris-glycin $\mathrm{pH} 8,6$ ) and saccharose $40 \%$ in the same proportions.

Only one or two enzymes were scored per specimen. The hemocyanic fractions and the following enzymes were analysed: amylases (AMY, EC 3.2.1.1.), 
phosphoglucose isomerase (PGI, EC 5.3.1.9.), alkaline phosphatase (ALP, EC 3.1.3.1.), aldehyde oxidases (AO, EC 1.2.3.1), malate dehydrogenases (MDH, EC 1.1.1.37), glutamic oxaloacetic transaminase (GOT, EC 2.6.1.1.), lactate dehydrogenase (LDH, EC 1.1.1.27.), esterases (EST, EC 3.1.1.1.). The technical details were described by Sims [27], Harris and Hopkinson [13], Legrand-Hamelin et al. [17], Laulier [14], Pasteur et al. [24] and CharfiCheikhrouha [5]. According to the population, the number of specimens varied from 14 to 184 .

Genetic interpretation of the gels was based upon the nomenclature of Pasteur et al. [24]: the most common allele at each locus was named 100. For the other alleles, numerical values were obtained by adding or subtracting migration distances from 100.

The Biosys-1 program of Swofford and Selander [29] was used:

- to calculate the coefficients $[20,21]$ of genetic identity (I) and genetic distance (D);

- to construct the phylogenetic tree using the unweighted pair group method (UPGMA) and the single linkage (SL) or nearest-neighbour method [28].

This last method offers the advantage of requiring no assumptions about equal rates of evolution.

\section{RESULTS}

\subsection{Experimental cross-breedings}

Owing to the cannibalism of males against females during ecdysis, only some cross-breedings were realized in the laboratory. The interspecies crossbreedings (I. balthica basteri I. c. mediterranea and I. c. bocqueti) were unsuccessful. The intersubspecies cross-breedings (I. c. mediterranea and $I$. c. bocqueti) yielded viable and fertile individuals. The intrasubspecies cross-breedings (I. c. mediterranea, I. c. bocqueti and I. c. chelipes) were always successful. The progeny numbers produced by the intra and the inter cross-breedings (table $I$ ) were compared statistically. The $F$ test application indicates no statistical difference between the matings $(F=0.1383, P<0.05)$.

\subsection{Electrophoretic analysis}

\subsubsection{Allozyme variation}

Genetic variation was examined at 13 loci in 12 populations of $I$. chelipes. Seven loci were found monomorphic in all populations: AO-1, MDH-1, MDH-2, GOT, LDH, EST-1 and hemocyanin (HCY). Six loci were polymorphic: AMY1, AMY-2, PGI, ALP, AO-2, EST-2. The number of alleles varied from 2 to 6. Enzyme structure, deduced from pedigree analysis, is monomeric (AMY, AO-2) or dimeric (ALP, EST-2).

Table II indicates allelic frequencies for the different $I$. chelipes populations. At the esterase locus (EST-2), diagnostic alleles were identified: each subspecies is characterized by its own allele. According to this table, we can observe that the alleles with the highest frequencies are the same in each subspecies. 
Table I. Intra and intersubspecific cross-breeding results.

\begin{tabular}{lcccc}
\hline $\begin{array}{l}\text { Cross-breeding } \\
\text { type }\end{array}$ & $\begin{array}{c}\text { I. c. } \\
\text { mediterranea }\end{array}$ & $\begin{array}{c}\text { I. c. } \\
\text { bocqueti }\end{array}$ & $\begin{array}{c}\text { Male } \\
\text { c. mediterranea } \\
\times\end{array}$ & $\begin{array}{c}\text { Male } \\
\text { c. bocqueti } \\
\times \\
\text { female } \\
\text { f. bocquetti }\end{array}$ \\
$\begin{array}{l}\text { Cross-breedings } \\
\begin{array}{l}\text { Number } \\
\text { descendents }\end{array}\end{array}$ & 13 & 10 & 12 & 6 \\
$\begin{array}{l}\text { Mean } \\
\text { variance }\end{array}$ & 14.15 & 13.60 & 12.50 & 13.80 \\
\hline
\end{tabular}

For some genes, frequencies differ notably between the three subspecies. Such results are observed when I. c. bocqueti is compared with the other I. chelipes subspecies (AMY-2). The same results are also observed within I.chelipes mediterranea when the northern lagoons of Tunisia are compared with the ponds of Roussillon (PGI).

The similarity of hemocyanin fractions was observed. The homology of the fraction, considered as the constitutive monomer, was demonstrated. These observations support the hypothesis of the hemocyanic allele identity.

Only nine loci were scored in the I. balthica basteri population. Three of them were polymorphic (AMY-1, PGI, LDH) and six were monomorphic withinpopulation (AMY-2, GOT, MDH-2, MDH-1, EST-1, HCY). The monomorphic loci are as important as the polymorphic ones. The three last loci were considered as biochemical markers. They separate I. b. basteri from I. chelipes samples. Allele frequencies are compiled in table II.

\subsubsection{Genetic divergence}

The genetic similarity (I) and distance (D) values were calculated among I. chelipes subspecies on the basis of the allelic frequency data (table III). (I) varies from 0.776 to 0.999 and (D) varies from 0.001 to 0.254 according to Nei [20]. Nei's unbiased [21] estimates of similarity and genetic distance varied, respectively, from 0.777 to 1 and from 0 to 0.252 .

Genetic distance values (table III) are low $(0.001<D<0.051)$ when comparing populations of the same subspecies. They notably increase when populations of the different subspecies are considered. The average values are equal to 0.109 (I. c. chelipes and I. c. mediterranea), to 0.118 (I. c. bocqueti and I. c. mediterranea) and to 0.211 (I. c. chelipes and I. c. bocqueti).

The interspecific genetic distances (table IV), based on nine loci are high $(d=0.898)$ when comparing the two species, I. b. basteri and I. chelipes. The average values are, respectively, equal to $0.996,0.955$ and 0.7435 between I.b.basteri and I. c.chelipes populations, I. c. mediterranea and I.c. bocqueti ones. 
F. Charfi-Cheikhrouha et al.

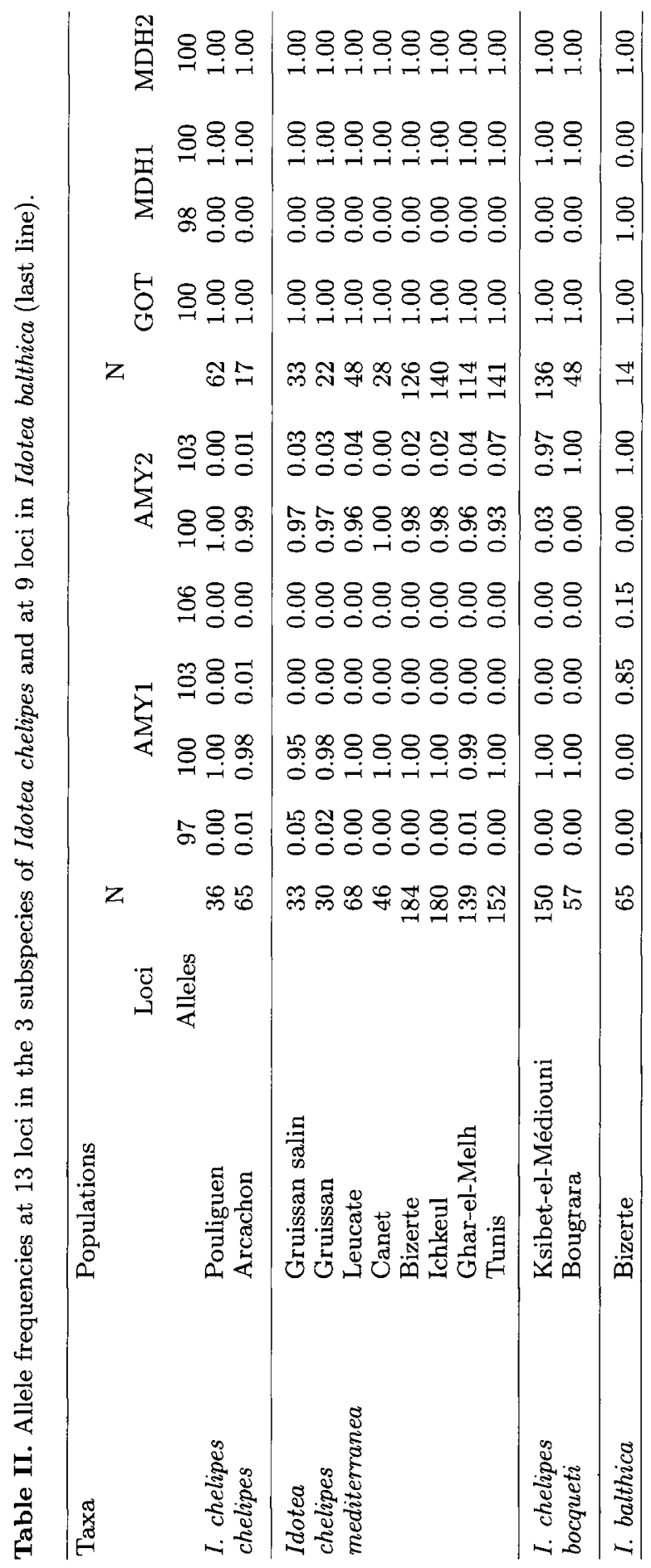




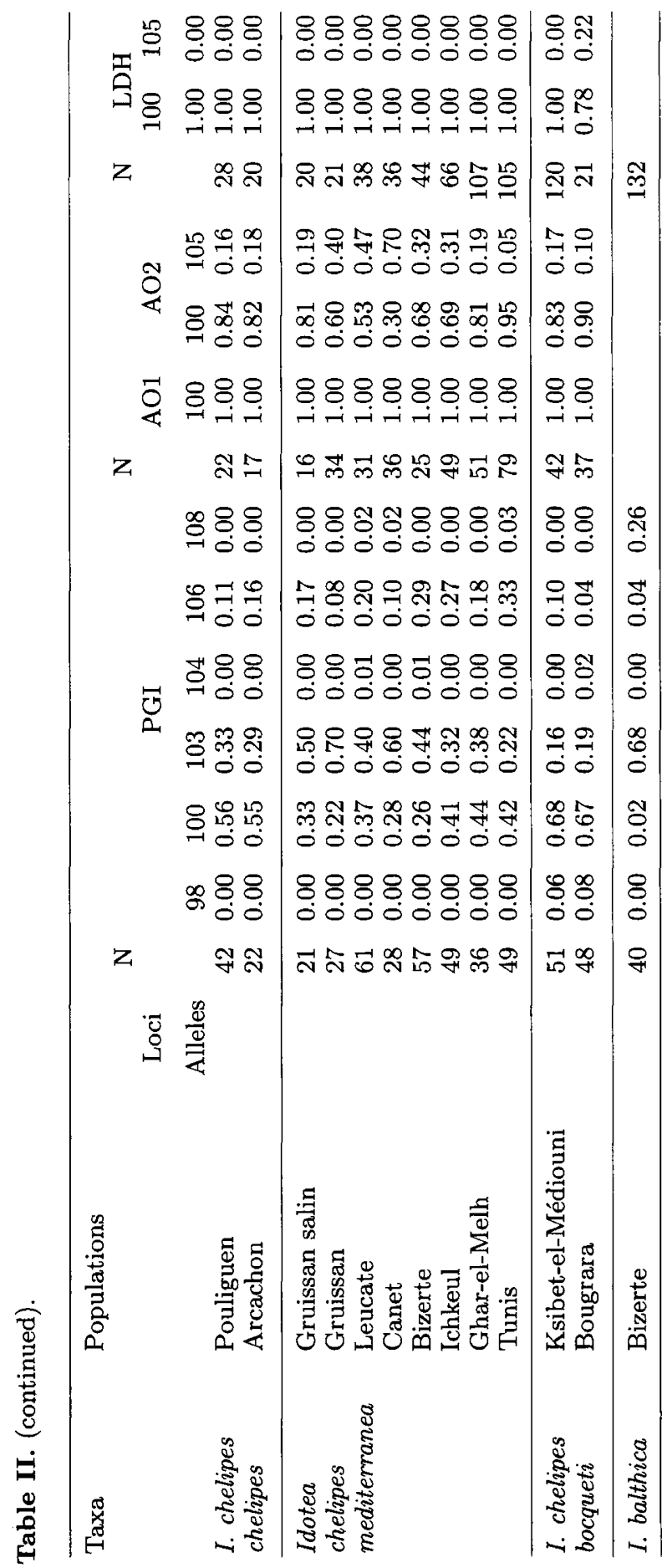


F. Charfi-Cheikhrouha et al.

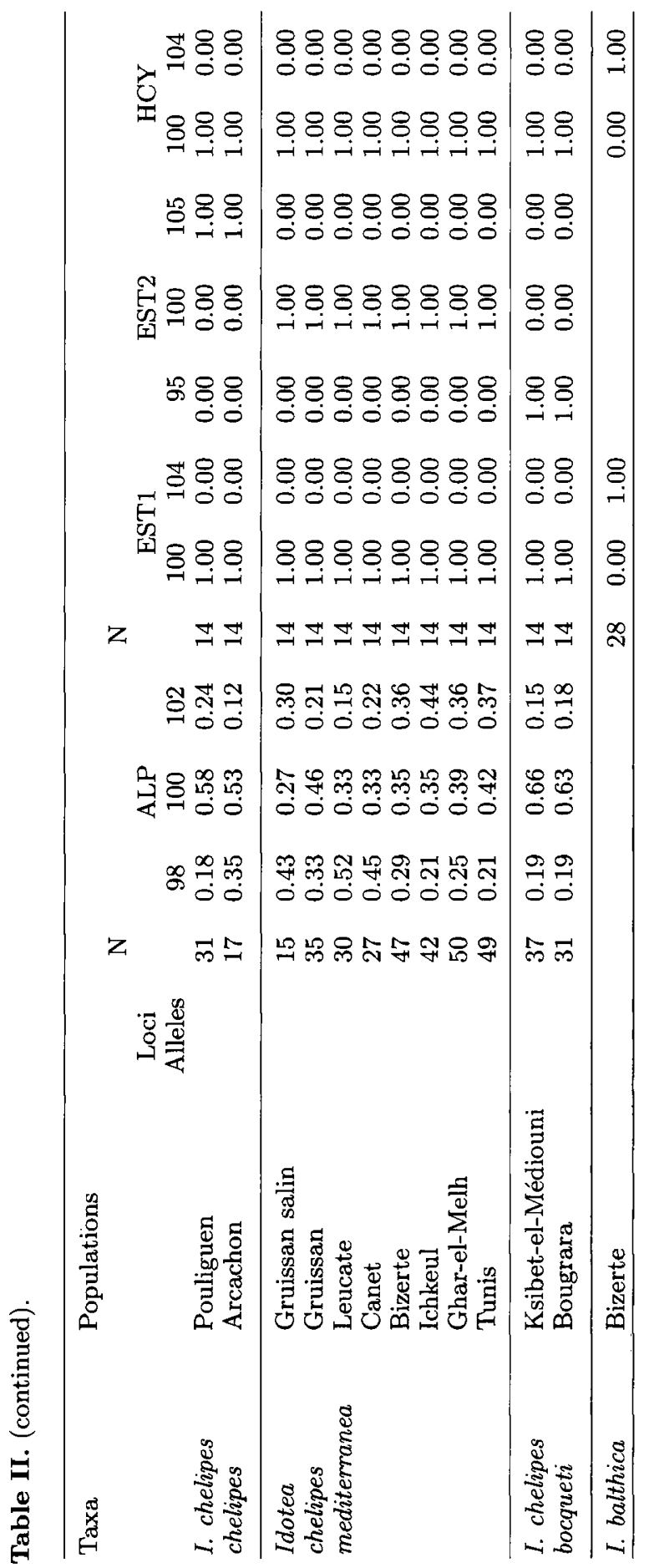




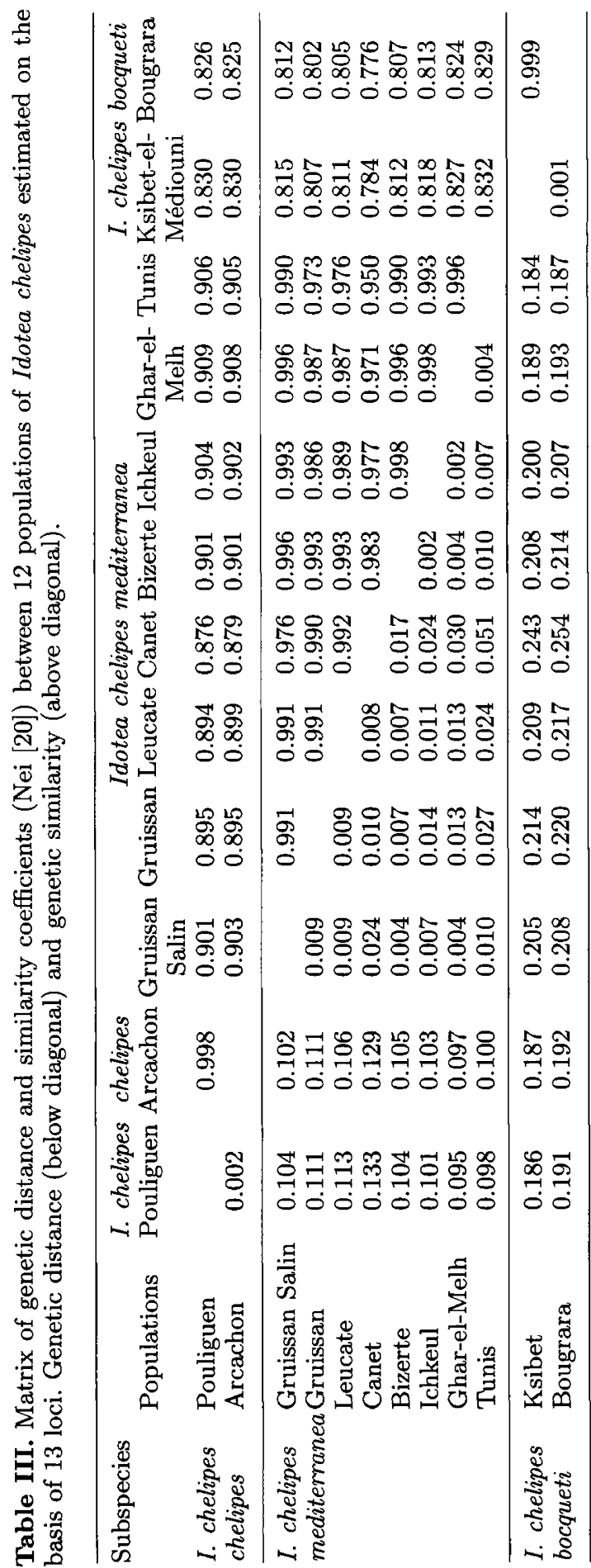




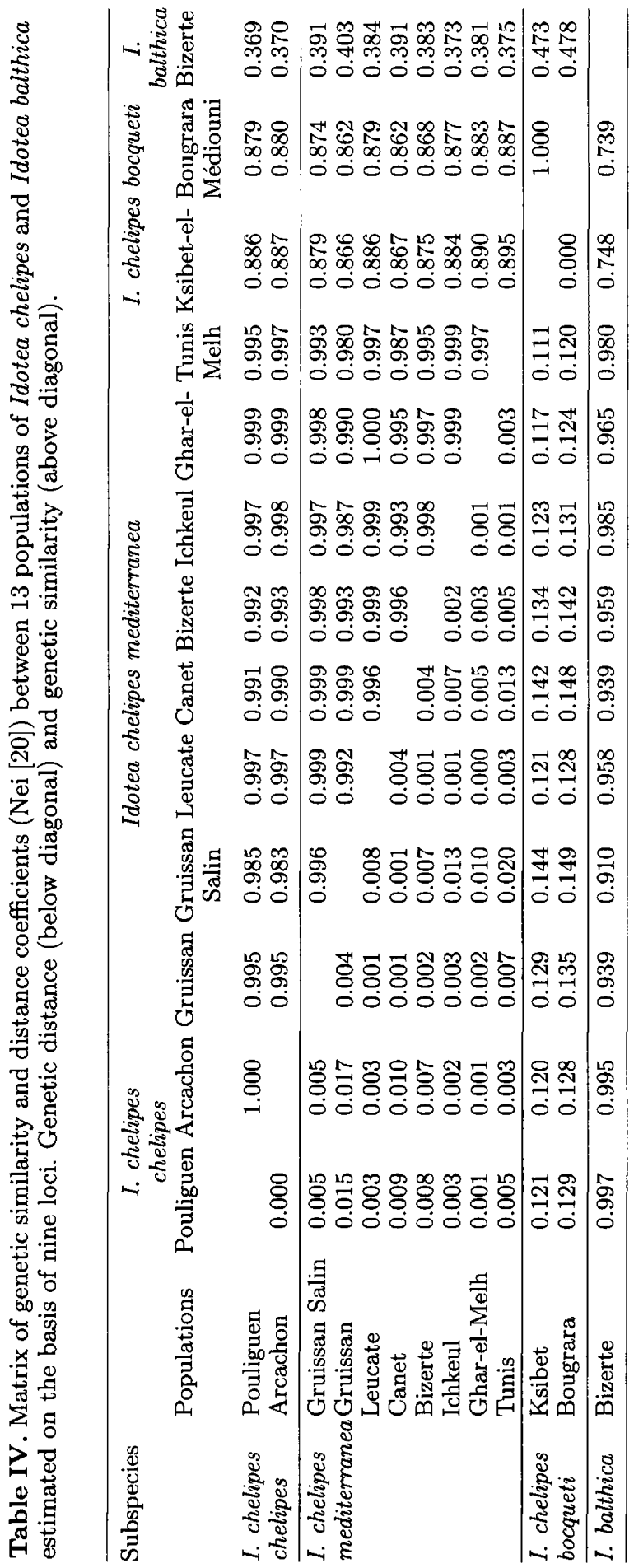


The dendrogram reported in figure 2 summarizes genetic relationships among all populations. It shows three levels of genetic differentiation corresponding to three main clusters:

- a first subdivision which separates the two species, I. b. basteri and I. chelipes;

- a second subdivision which isolates I. c. bocqueti populations from I. $c$. chelipes and I. c. mediterranea ones;

- a third subdivision which separates I. c. mediterranea and I.c.chelipes populations.

The groupings of the various populations of I.c. mediterranea, using the UPGMA and the SL methods, are different. These populations are represented on the dendrogram at the same level.

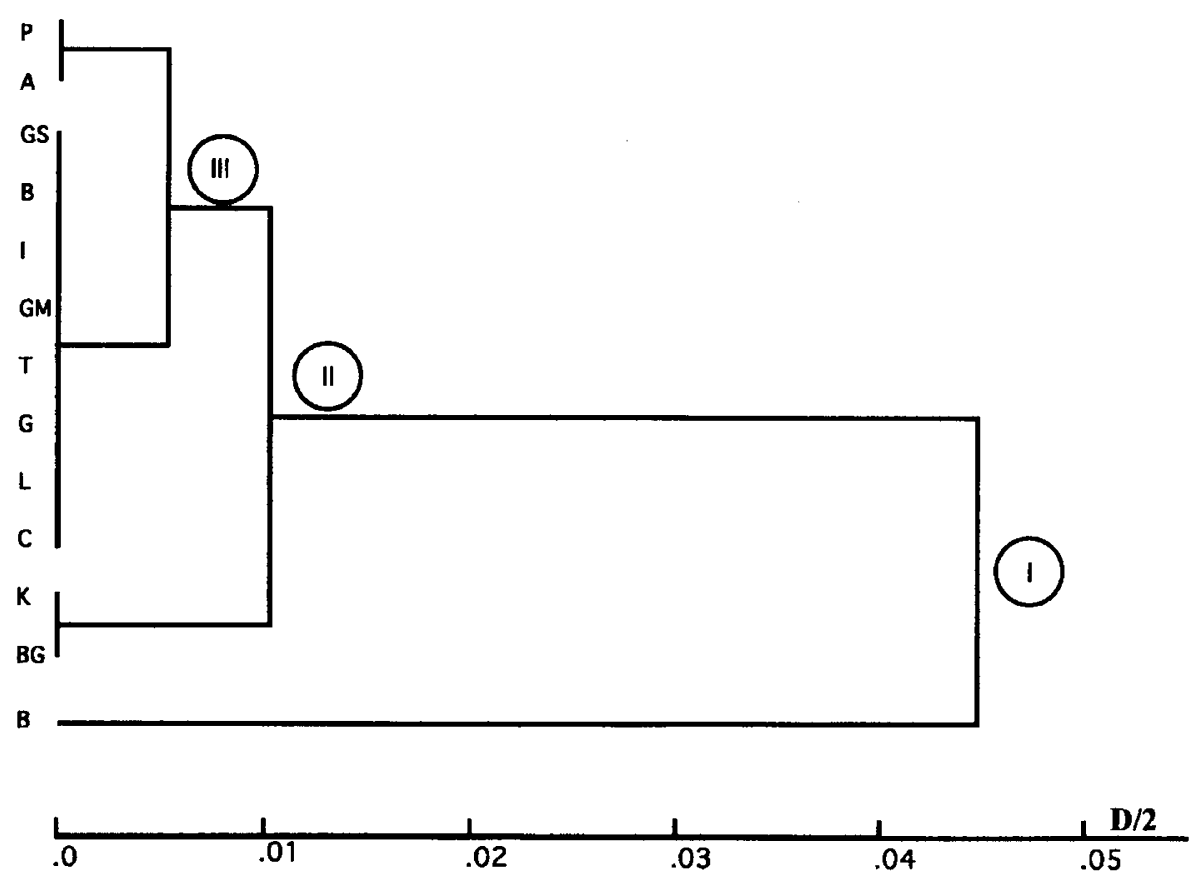

Figure 2. Dendrogram of Idotea chelipes populations based on UPGMA clustering of the genetic distance (D) data reported in table III. Data reported in table IV for the specific cladogenetic event (Level I).

\section{DISCUSSION}

Experimental studies showed the similarity of interbreedings between and within I. chelipes subspecies. Negative results and unsuccessful matings were observed when I. b. basteri was involved. According to the biological species concept: the mating of $I$. bocqueti sensu Rezig with other I. chelipes populations 
produces hybrid offspring that interbreed with both parents and with one another [6]. We conclude that $I$. bocqueti is not a 'good' species like I. b. basteri but a race or a subspecies which belongs to the same species I. chelipes. However, these conclusions would be confirmed by further experiments based on the possibility of the choice of partners and the investigation of sympatric areas such as the Siculo Tunisia strait.

Apart from the morphological similarities, there are diagnostic alleles at the esterase 2 locus which constitute the best way to characterize hybrids in potential contact zones. At the locus EST-2 of the hybrids $I$. c. bocqueti I. c. mediterranea, three bands at equal distances are evident. This result proves a diallelic locus and a dimeric structure of the EST-2.

Like other Crustaceans, the hemocyanic electrophoregram might be used as a specific taxonomic criterion. Manwell and Baker [19] and Maguire and Fielder [18] reported a similar hemocyanin pattern of various Crustacean species. Furthermore, in the case of Sphaeroma, the hemocyanin is both specific and subspecific [15]. In the Idotea genus, the comparison of hemocyanic fractions showed the identity of I. c. chelipes, I. c. mediterranea and I. c. bocqueti. This pattern differs from that of $I . b$. basteri [9]. These results are consistent with the hypothesis of genetic identity of the hemocyanin fraction inside closely related taxa.

An interesting observation should be made: the genetic distinction of the three subspecies is related to the geographic areas based on the enzymatic polymorphism and the allelic frequencies. Many geographically distinct populations of Jaera, Talitrus saltator were separated when allelic frequencies were used $[3,11]$.

The genetic distance values (table IV) might be directly compared with the taxonomic categories based on morphological criteria. The interspecific (chelipes-balthica) genetic distance as well as the subspecific one (c. bocqueti, c. mediterranea and c. chelipes) agree with estimates reported for other animal groups [2, 23]. The former values confirm that populations of the western Mediterranean and the Atlantic lagoons of $I$. chelipes would be considered as local populations of the two subspecies, I. chelipes mediterranea and I. chelipes chelipes and suggest that $I$. bocqueti cannot be isolated from the $I$. chelipes complex and elevated to the rank of species like I. balthica basteri. This example shows the excellent overall agreement between the genetic data and the taxonomic grouping.

The genetic distances within I. chelipes subspecies were used to draw the dendrogram (figure 2). The results suggest a relatively recent separation of the three subspecies populations. The first cladogenetic event would isolate the two species, I. chelipes and I. balthica. The second one would lead to the separation of I. c. bocqueti from I. c. mediterranea-I. c. chelipes and the third one would separate I. c. mediterranea and I. c. chelipes. It would be important to examine, with particular attention, the presumed contact zones considering that the process of geographic differentiation is reversible, whether there is an opportunity of gene exchange.

The clustering in the dendrogram agrees with the morphological affinities. The two species, I. chelipes and I. balthica basteri, are distinguishable by strong features notably the male sexual characteristics such as appendix masculina and pereiopod's two seta. Only minor features corresponding to the pleotelson and 
the first pereionite shape are observed to differ within I. chelipes subspecies. Thus, these characteristics are more pronounced in 1. c. bocqueti than in the two other I. chelipes subspecies.

The results of the genetic analysis confirm our morphological observations and our tests of tentative hybridization and reinforce our hypothesis of the distinction of three subspecies, I. c. bocqueti, I. c. mediterranea and I. c. chelipes of a single polytypic species $I$. chelipes.

Contrary to some assertions [30,31] for Idotea balthica [16] for Sphaeroma, the pattern of $I$. chelipes would suggest colonization from the western Mediterranean sea [10]. These apparently contradictory results must be reconsidered. The present Mediterranean Isopoda fauna might be related to a conquest by species which originated from the present oriental basin and which did not undergo drying during the salinity crisis as expounded by Charfi-Cheikhrouha and Zaghbib-Turki [10] and a reconquest by Atlantic species [25, 16]. To better solve this puzzle, the study must be enlarged to other species of the Idotea genus. The cladogram obtained must be compared with the corresponding geological events as has been carried out for Jaera genus on the basis of morphological characters [32].

\section{ACKNOWLEDGEMENT}

We are grateful to the referees for their comments and correction.

\section{REFERENCES}

[1] Audouin J.V., Explication sommaire des planches des crustacés de l'Egypte et de la Syrie, J. C. Savigny, 1827.

[2] Ayala F., Biologie moléculaire et évolution, Masson, Paris, 1982.

[3] Cariou M.L., Polymorphisme enzymatique et relations phylogénétiques des espèces du complexe Jaera albifrons (Crustacés, Isopodes), Bull. Off. Natl. Pêche Tunisie 3 (1979) 55-58.

[4] Charfi-Cheikhrouha F., Complément à la définition 'Idotea chelipes, espèce polytypique' à partir des fractions protéiques et particulièrement de l'hémocyanine. Comparaison avec Idotea balthica basteri. Aspects récents de la biologie des Crustacés, Actes de Colloques 8 Ifremer, 1988, pp. 199-202.

[5] Charfi-Cheikhrouha F., Polytypisme d'Idotea chelipes (Pallas), Crustacé, Isopode, Valvifere - Comparaison avec Idotea balthica basteri, thèse Univ. Tunis II, 1990, pp. 1-323.

[6] Charfi-Cheikhrouha F., Développement post-embryonnaire de deux sousespèces, Idotea chelipes bocqueti et Idotea chelipes mediterranea et de leurs hybrides (Crustacés, Isopodes, Valvifères), Bull. Soc. Sci. Nat. Tunisie 23 (1994) 36-42.

[7] Charfi-Cheikhrouha F., Estérase et amylase : deux marqueurs biochimiques chez l'espèce polytypique Idotea chelipes (Crustacé, Isopode Valvifère), Arch. Inst. Pasteur Tunis 71 (1-2) (1994) 13-20.

[8] Charfi-Cheikhrouha F., Idotea chelipes (Pallas, 1766), espèce polytypique : description de ses sous-espèces (Isopodes, Valvifères), Crustaceana 69 (1996) 187-203.

[9] Charfi-Cheikhrouha F., Belhadj O., Étude électrophorétique de l'hémocyanine de l'espèce polytypique Idotea chelipes et d'Idotea balthica basteri (Crustacés, Isopodes), C. R. Acad. Sci. Paris 314 (1992) 193-197. 
[10] Charfi-Cheikhrouha F., Zaghbib-Turki D., L'horloge moléculaire et la dispersion biogéographique d'Idotea chelipes (Crustacea, Isopoda, Valvifera), Rev. Palébiol. 10 (1991) 423-430.

[11] De Matthaeis E., Cobolli M., Mattoccia M., Scapini F., Geographic variation in Talitrus saltator (Crustacea, Amphipoda): biochemical evidence, Boll. Zool. 62 (1995) 77-84.

[12] Drach P., Tchernigovtzeff C., Sur la méthode de détermination des stades d'intermue et son application générale aux Crustacés, Vie et Milieu 18 (1967) 595-609.

[13] Harris H., Hopkinson D.A., Handbook of Enzyme Electrophoresis in Human Genetics, North-Holland Publishing Company, Amsterdam, 1976.

[14] Laulier M., Essai de génétique et de systématique évolutives de trois espèces du genre Sphaeroma Latreille (Isopodes flabellifères), thèse Univ. Maine, 1984, pp. 1144.

[15] Laulier M., Valeur taxonomique spécifique des sous unités hémocyaniques chez cinq espèces du genre Sphaeroma Latreille (Isopodes, Flabellifères), Bull. Soc. Zool. Fr. 109 (1985) 365-376.

[16] Laulier M., Génétique et systématique évolutives du complexe d'espèces Sphaeroma hookeri Leach, Sphaeroma levii Argano et Sphaeroma rugicauda Leach (Crustacés, Isopodes, Flabellifères), Genet. Sel. Evol. 21 (1989) 131-145.

[17] Legrand-Hamelin E., Souty C., Picaud J.L., Le polymorphisme de la lactate déshydrogénase dans des sous-espèces d'Idotea balthica, Biochem. System. Ecol. 10 (1982) 79-81.

[18] Maguire G.B., Fielder D.R., Disc electrophoresis of the haemolymph proteins of some Portunid crabs (Decapoda : Portunidæ). II Physiological and taxonomic aspects, Comp. Biochem. Physiol. 52 (1975) 43-47.

[19] Manwell C., Ann Baker C.M., Starch gel electrophoresis of sera from marine Arthropodes : studies of the heterogeneity of hemocyanin and on a 'cerruloplasminlike protein', Comp. Biochem. Physiol. 8 (1963) 193-208.

[20] Nei M., Genetic distance between populations, Am. Nat. 106 (1972) 283-292.

[21] Nei M., Estimation of average heterozygosity and genetic distance from a small number of individuals, Genetics 89 (1978) 583-590.

[22] Pallas P.S., Miscellanea Zoologica quibus novœ imprimis atque obscuræ, Animalium Species describuntur et Observationibus Iconibusque illustrantur, Paris, 1766, pp. 1-224.

[23] Pasteur G., Pasteur N., Les critères biochimiques et l'espèce animale, in: Les problèmes de l'espèce dans le règne animal III, Mem. Soc. Zool. France, Paris, 1980, pp. 99-150.

[24] Pasteur N., Pasteur G., Bonhomme F., Catalan J., Britton-Davidian J., Manuel technique de génétique par électrophorèse de protéines, Tec. \& Doc. Lavoisier, Paris, 1987.

[25] Pomerol C., Stratigraphie et paléogéographie. Ère Cénozoïque (Tertiaire et Quaternaire), Doin, Paris, 1973.

[26] Rezig M., Description d'une nouvelle idotée des côtes méditerranéennes, Idotea bocqueti n. sp. (Isopode, Valvifère), Bull. Soc. Sci. Nat. Tunisie, 12 (1977) $53-56$.

[27] Sims M., Methods of detection of enzymatic activity after electrophoresis on polyacrylamide gel in Drosophila species, Nature 207 (1965) 757-758.

[28] Sneath P.H.A., Sokal R.R., Numerical Taxonomy, Freeman, San Francisco, 1973. 
[29] Swofford D.L., Selander R.B., Biosys-1: a Fortran program for the comprehensive analysis of electrophoretic data in population genetics and systematics, J. Hered. 72 (1981) 281-283.

[30] Sywula T., A study on the taxonomy, ecology and geographical distribution of species of the genus Idotea fabricius (Isopoda, Crustacea) in polish Baltic. I. Taxonomical part, Bull. Soc. Sci. Lett. Poznan 4 D (1964) 173-200.

[31] Tinturier-Hamelin E., Polychromatisme et détermination génétique du sexe chez l'espèce polytypique Idotea balthica (Pallas) Isopode, Valvifère, Cah. Biol. Mar. 4 (1963) $479-591$

[32] Veuille M., L'évolution du genre Jaera Leach (Isopodes; Asellotes) et ses rapports avec l'histoire de la Méditerranée, Bijdragen tot de Dierkunde 49 (1979) $195-217$. 